\title{
Communication
}

\section{Chemical Constituents of Excoecaria acerifolia and Their Bioactivities}

\author{
Yan-Li Zhao ${ }^{1,2}$, Qiu-Xia He ${ }^{3}$, Yang $\mathrm{Li}^{1}$, Si-Feng Wang ${ }^{3}$, Ke-Chun Liu ${ }^{3}$, \\ Yong-Ping Yang ${ }^{1,4, *}$ and Xiao-Li Li ${ }^{1,4, *}$
}

1 Laboratory of Ethnobotany, Kunming Institute of Botany, Chinese Academy of Sciences, Kunming 650204, Yunnan, China; E-Mails: zhaoyanli@mail.kib.ac.cn (Y.L.Z.); liyang@mail.kib.ac.cn (Y.L.);

2 Graduate University of Chinese Academy of Sciences, Beijing 100039, China;

3 Biology Institute of Shandong Academy of Sciences, Jinan 250014, Shandong, China; E-Mails: heqiuxia8008@163.com (Q.X.H.); peakwang10@gmail.com (S.F.W.); hliukch@keylab.net (K.C.L.)

4 Institute of Tibetan Plateau Research at Kunming, Kunming Institute of Botany, Chinese Academy of Sciences, Kunming 650204, Yunnan, China

* Authors to whom correspondence should be addressed; E-Mails: yangyp@mail.kib.ac.cn (Y.P.Y.); li_xiaoli11@mail.kib.ac.cn (X.L.L.); Tel.: +86-871-5223231; Fax: +86-871-5223231.

Received: 29 December 2009; in revised form: 12 February 2010 / Accepted: 8 March 2010 / Published: 26 March 2010

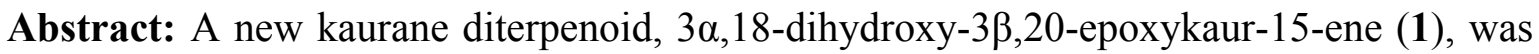
isolated from the aerial parts of Excoecaria acerifolia (Euphorbiaceae) together with 16 known compounds. Their structures were identified by extensive spectral analysis, especially 2D NMR techniques. Antiangiogenic effects of compounds 1-6 and 9-17 were evaluated using a zebrafish model, with compound 9 being active in this bioassay. At the same time, compounds 4, 6, 10, 11 showed activity in inhibiting the growth of A549 lung cancer cells, and the compound $\mathbf{1 0}$ also showed apoptosis-inducing effects on A549 lung cancer cells.
\end{abstract}

Keywords: kaurane diterpenoid; Excoecaria acerifolia; NMR; antiangiogenic; antiproliferative 


\section{Introduction}

The genus Excoecaria of the plant family Euphorbiaceae, comprising 40 species, is wildly distributed in tropical Asia, Africa and Oceania. In China, there are five recorded Excoecaria species, of which E. agallocha has been well studied and a number of novel diterpenoids with anti-tumor bioactivity [1] and anti-HIV phorbol ester [2] found in it have been reported. However, no information concerning the chemical constituents of E. acerifolia has been published so far. The E. acerifolia plant is a dominant species of Maquis vegetation type distributed in the dry valleys in Southwest China [3-4]. Aiming to search for bioactive secondary products from E. acerifolia, we investigated the aerial

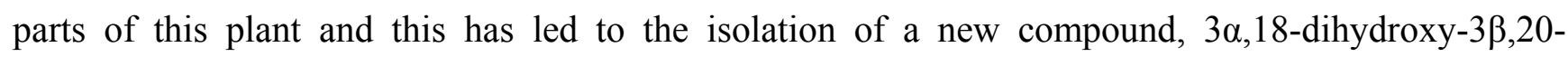

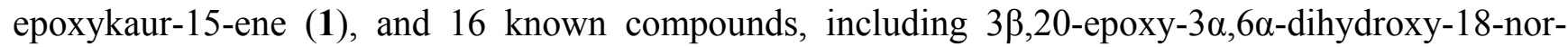
beyer-15-ene (2) [5], catechin (3) [6], kaempferol (4) [7], quercetin (5) [8], 5,7-dihydroxy-3,4'dimethoxyflavone (6) [9], aromadendrin (7) [10], texifolin (8) [11], 6-dimethoxy-7dihydroxycoumarin (9) [12], trihydroxybenzoic acid (10) [13], progallin A (11) [14], shikimic acid (12) [15], shikimic acid Me ester (13) [15], (E)-p-coumatic acid (14) [16], m-hydroxybenzoic acid Me ester (15) [17], 3,4-dihydroxy-benzoic acid (16) [18] and phytol (17) [19] (Figure 1). This paper presented the results in the separation and structure elucidation of the new kaurane diterpenoid, and the antiangiogenic activities using a zebrafish model and the antiproliferative activities using A549 lung cancer cells of compounds 1-6 and 9-17.

\section{Results and Discussion}

Compound 1 was isolated as white crystals from methanol. Its HRESIMS indicated the molecular formula $\mathrm{C}_{20} \mathrm{H}_{30} \mathrm{O}_{3}$, as evidenced by the pseudo-molecular ion peak at m/z $341.2099[\mathrm{M}+\mathrm{Na}]^{+}$(calcd. 341.2092), corresponding to six degrees of unsaturation. IR absorption bands at 3,381, 2,919, 1,646 and $1,058 \mathrm{~cm}^{-1}$ implied the presence of hydroxyl, methylene, olefinic and ether groups, respectively. The ${ }^{1} \mathrm{H}-\mathrm{NMR}$ spectra exhibited two methyl groups as singlets $\left(\delta_{\mathrm{H}} 1.68,1.15\right)$. The ${ }^{13} \mathrm{C}-\mathrm{NMR}$ and DEPT spectra of 1 in $\mathrm{CDCl}_{3}$ showed 20 carbons with 28 directly attached protons for the diterpene nucleus (Table 1). The ${ }^{1} \mathrm{H}$ - and ${ }^{13} \mathrm{C}$-NMR spectra also showed the presence of a double bond, four tertiary carbons, and three oxygenated carbons in this molecule. Further analysis of $2 \mathrm{D}$ NMR spectra $\left({ }^{1} \mathrm{H}_{-}{ }^{1} \mathrm{H}\right.$ COSY, HMQC, ROESY and HMBC) lead to the construction of a structural formula for $\mathbf{1}$ based on an anthracene skeleton with an epoxy ring formed between C-3 and C-20, cis-olefins at C-8 and C-13, and a hydroxyl methyl groups at $\mathrm{C}-18$ to complete a kaurane skeleton, which was also supported by the characteristic peak of two angular methyl groups at $\delta_{\mathrm{H}} 1.68(3 \mathrm{H}, \mathrm{s})$ and $1.15(3 \mathrm{H}, \mathrm{s})$ [20-21]. The comparison of the 1D NMR data of 1 with those of the known compound excoecarin D [22], which was determined by X-ray diffraction, showed the ${ }^{1} \mathrm{H}$ - and ${ }^{13} \mathrm{C}-\mathrm{NMR}$ data of these two compounds were structurally similar. The differences can be rationalized to the position change of methyl-17 from C-13 in excoecarin D to C-16 in 1, which lead to the observation of only one olefinic proton $\left(\delta_{\mathrm{H}} 5.04\right)$ in 1 and one methine at $\mathrm{C}-13$ in $\mathbf{1}$ other than a quaternary carbon in excoecarin $\mathrm{D}$. This deduction was established by the HMBC correlations of the methyl group $\left(\delta_{\mathrm{H}} 1.68, \mathrm{C}-17\right)$ with $\delta_{\mathrm{C}} 42.1$ (C-13), 133.3 (C-15) and 142.4 (C-16). 
The relative configurations of $\mathbf{1}$ were determined on the basis of ROESY experiments. The olefinic proton at $\mathrm{C}-15$ correlated with the methylene protons at $\mathrm{C}-20$ and the protons at $\mathrm{CH}_{3}-17$. ROESY correlations of $\mathrm{H}-5$ with the protons of the oxygenated methylene $(\mathrm{C}-18)$ and $\mathrm{H}_{2}-20$ with $\mathrm{H}-19$ indicated C-18 were $\alpha$-orientated. ROESY correlations of $\mathrm{H}-9$ with $\mathrm{H}_{2}-14$ showed both $\mathrm{H}-9$ and $\mathrm{C}-14$ are on the same face of the molecule with $\alpha$-orientation. Therefore, the structure of 1 was established as $3 \alpha, 18$-dihydroxy-3 $\beta, 20$-epoxykaur-15-ene.

Figure 1. The structures of compounds 1-17.

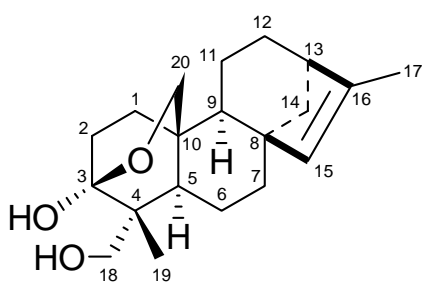

1<smiles>[R]c1ccc(-c2oc3cc(O)cc(O)c3c(=O)c2[R3])cc1[R]</smiles>

$4 \mathrm{R}_{1}=\mathrm{H}, \mathrm{R}_{2}=\mathrm{OH}, \mathrm{R}_{3}=\mathrm{OH}$

$5 \mathrm{R}_{1}=\mathrm{R}_{2}=\mathrm{R}_{3}=\mathrm{OH}$

$6 \mathrm{R}_{1}=\mathrm{H}, \mathrm{R}_{2}=\mathrm{R}_{3}=\mathrm{OMe}$<smiles>[R]OC(=O)c1cc(O)c(O)c(O)c1</smiles>

$10 \mathrm{R}=\mathrm{H}$

$11 \mathrm{R}=\mathrm{CH}_{3} \mathrm{CH}_{2}$<smiles>COC(=O)c1cccc(O)c1</smiles>

15

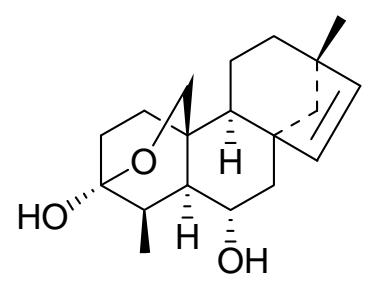

2<smiles>[R2]c1ccc([C@H]2Oc3cc(O)cc(O)c3C(=O)[C@@H]2O)cc1[R]</smiles>

$7 \mathrm{R}_{1}=\mathrm{H}, \mathrm{R}_{2}=\mathrm{OH}$

$8 \mathrm{R}_{1}=\mathrm{R}_{2}=\mathrm{OH}$<smiles>[R]OC(=O)C1=C[C@@H](O)[C@H](O)[C@H](O)C1</smiles>

$12 \mathrm{R}=\mathrm{H}$

$13 \mathrm{R}=\mathrm{Me}$<smiles>O=C(O)c1ccc(O)c(O)c1</smiles>

16<smiles>Oc1cc(O)c2c(c1)O[C@H](c1ccc(O)c(O)c1)[C@H](O)C2</smiles>

3<smiles>COc1cc2ccc(=O)oc2cc1O</smiles>

9<smiles>O=C(O)/C=C/c1ccc(O)cc1</smiles>

14<smiles>CC(=CCO)CCC1CCCCC1CCCC(C)(C)C</smiles>

17 
Table 1. The NMR data of 1 (in $\mathrm{CDCl}_{3}$ ).

\begin{tabular}{cll|cll}
\hline Position & $\boldsymbol{\delta}_{\mathbf{C}}$ & $\boldsymbol{\delta}_{\mathbf{H}}$ & Position & $\boldsymbol{\delta}_{\mathbf{C}}$ & $\boldsymbol{\delta}_{\mathbf{H}}$ \\
\hline $1 \mathrm{a}$ & $30.2(\mathrm{t})$ & $1.18(\mathrm{~m})$ & $11 \mathrm{a}$ & $19.2(\mathrm{t})$ & $1.12(\mathrm{~m})$ \\
$1 \mathrm{~b}$ & & $1.58(\mathrm{~m})$ & $11 \mathrm{~b}$ & & $1.49(\mathrm{~m})$ \\
$2 \mathrm{a}$ & $24.5(\mathrm{t})$ & $1.61(\mathrm{~m})$ & $12 \mathrm{a}$ & $34.9(\mathrm{t})$ & $1.18(\mathrm{~m})$ \\
$2 \mathrm{~b}$ & & $1.40(\mathrm{~m})$ & $12 \mathrm{~b}$ & & $1.58(\mathrm{~m})$ \\
3 & $98.6(\mathrm{~s})$ & $/$ & 13 & $42.1(\mathrm{~d})$ & $2.19(\mathrm{~d}, 5.7)$ \\
4 & $43.9(\mathrm{~s})$ & $/$ & $14 \mathrm{a}$ & $44.7(\mathrm{t})$ & $1.12(\mathrm{~m})$ \\
5 & $45.9(\mathrm{~d})$ & $1.43(\mathrm{~m})$ & $14 \mathrm{~b}$ & & $1.49(\mathrm{~m})$ \\
$6 \mathrm{a}$ & $20.6(\mathrm{t})$ & $1.12(\mathrm{~m})$ & 15 & $133.3(\mathrm{~d})$ & $5.04(\mathrm{~s})$ \\
$6 \mathrm{~b}$ & & $1.49(\mathrm{~m})$ & 16 & $142.4(\mathrm{~s})$ & $/$ \\
$7 \mathrm{a}$ & $36.4(\mathrm{t})$ & $1.78(\mathrm{~m})$ & 17 & $15.4(\mathrm{q})$ & $1.68(\mathrm{~s})$ \\
$7 \mathrm{~b}$ & & $1.53(\mathrm{~m})$ & $18 \mathrm{a}$ & $70.2(\mathrm{t})$ & $3.66(\mathrm{~d}, 11.0)$ \\
8 & $48.2(\mathrm{~s})$ & $/$ & $18 \mathrm{~b}$ & & $3.30(\mathrm{~d}, 11.0)$ \\
9 & $43.8(\mathrm{~d})$ & $1.46(\mathrm{~m})$ & 19 & $13.4(\mathrm{q})$ & $1.15(\mathrm{~s})$ \\
10 & $36.5(\mathrm{~s})$ & $/$ & $20 \mathrm{a}$ & $68.0(\mathrm{t})$ & $4.43(\mathrm{dd}, 8.5,2.0)$ \\
& & & $20 \mathrm{~b}$ & & $3.86(\mathrm{dd}, 8.5,2.0)$ \\
\hline
\end{tabular}

${ }^{\text {a }}$ Spectra were obtained at $400\left({ }^{1} \mathrm{H}-\mathrm{NMR}\right)$ and $100\left({ }^{13} \mathrm{C}-\mathrm{NMR}\right) \mathrm{MHz}$ in $\mathrm{CDCl}_{3}$ and chemical shifts $(\delta)$ are in ppm with $J$ values in $\mathrm{Hz}$.

Figure 2. Key $\mathrm{HMBC}(\rightarrow)$ and ${ }^{1} \mathrm{H},{ }^{1} \mathrm{H}$ COSY $(-)$ correlations of $\mathbf{1}$.

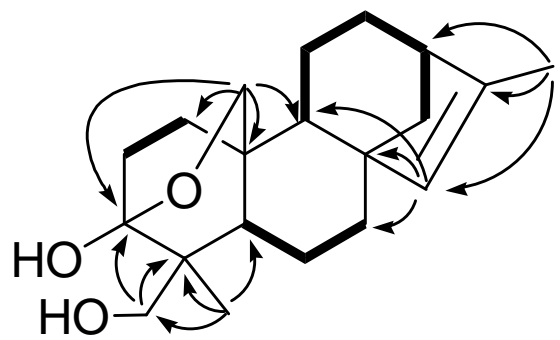

\section{Biological Acticity}

The antiangiogenic activities of compounds 1-6 and 9-17 were evaluated using a zebrafish model, in terms of the inhibition on the growth of intersegmental vessels, with PTK787 as positive control $\left(\mathrm{IC}_{50} 0.15 \mu \mathrm{g} / \mathrm{mL}\right.$ ) [23]. The results showed that intersegmental vessels of embryos treated with compound 9 was significantly less than that of the control (0.1\% DMSO in sterile salt water). The inhibition ratio of compound 9 was $64.9 \%$ at a concentration of $50 \mu \mathrm{g} / \mathrm{mL}$ (Table 2). The antiproliferative activities of compounds 1-6 and 9-17 were evaluated using A549 lung cancer cells by MTT assay [24]. The results indicated that compounds 4, 6, 10 and 11 showed a certain extent antiproliferative activities (Table 3). From the photos of acridine orange staining, compound $\mathbf{1 0}$ showed obvious effect of inducing apoptosis of A549 lung cancer cells (Figure 3). Other tested compounds didn't show any obvious antiangiogenic and antiproliferative bioactivities. 
Table 2. Anti-angiogenic activity of compounds 1-6, 9-17.

\begin{tabular}{|c|c|c|c|}
\hline Compound & $\begin{array}{c}\text { Concentration } \\
(\mu \mathrm{g} / \mathrm{mL})\end{array}$ & $\begin{array}{c}\text { Intersegmental Vessels } \\
\text { (ISV) }\end{array}$ & Inhibition Ratio (\%) \\
\hline 1 & 100 & $24.7 \pm 1.2$ & 8.0 \\
\hline 2 & 100 & $26.7 \pm 1.2$ & 0.5 \\
\hline 3 & 100 & $26.0 \pm 0.0$ & 3.0 \\
\hline 4 & 100 & $24.7 \pm 1.2$ & 8.0 \\
\hline 5 & 100 & $24.7 \pm 1.2$ & 8.0 \\
\hline 6 & 100 & $20.0 \pm 2.8$ & 25.4 \\
\hline 9 & 50 & $9.4 \pm 8.4 * *$ & 64.9 \\
\hline 10 & 100 & $26.7 \pm 1.2$ & 0.5 \\
\hline 11 & 100 & $26.7 \pm 1.2$ & 0.5 \\
\hline 12 & 100 & $26.3 \pm 1.5$ & 1.7 \\
\hline 13 & 100 & $24.7 \pm 0.6$ & 8.0 \\
\hline 14 & 100 & $26.3 \pm 0.6$ & 1.7 \\
\hline 15 & 100 & $25.0 \pm 0.0$ & 6.7 \\
\hline 16 & 100 & $24.7 \pm 2.3$ & 8.0 \\
\hline 17 & 100 & $27.0 \pm 1.0$ & 0 \\
\hline control $^{a}$ & & $26.8 \pm 1.8$ & \\
\hline PTK787 & 10 & $0 * *$ & 100 \\
\hline
\end{tabular}

${ }^{a} 0.1 \%$ DMSO in sterile salt water; $* *$ means that the value was significantly different from the control and $p<0.01$.

Table 3. Inhibitory effect of compounds 4, 6, 10, 11 on the proliferation of A549 lung cancer cells.

\begin{tabular}{c|lll}
\hline \multirow{2}{*}{$\begin{array}{c}\text { M(\%) } \\
\text { Compounds }\end{array}$} & \multicolumn{3}{|c}{ Concentration } \\
\cline { 2 - 4 } & $\mathbf{2 5} \boldsymbol{\mu g} / \mathbf{m L}$ & $\mathbf{5 0} \boldsymbol{\mu g} / \mathbf{m L}$ & $\mathbf{1 0 0} \boldsymbol{\mu g} / \mathbf{m L}$ \\
\hline $\mathbf{4}$ & $12.78 \pm 6.56$ & $40.8 \pm 2.96^{* *}$ & $52.51 \pm 2.97^{* *}$ \\
$\mathbf{6}$ & $14.35 \pm 0.61^{* *}$ & $48.76 \pm 5.08^{* *}$ & $62.03 \pm 5.72^{* *}$ \\
$\mathbf{1 0}$ & $15.92 \pm 3.12^{* *}$ & $61.13 \pm 2.49^{* *}$ & $74.6 \pm 2.28^{* *}$ \\
$\mathbf{1 1}$ & $22.38 \pm 8.37$ & $26.47 \pm 5.25^{* *}$ & $48.6 \pm 6.76^{* *}$ \\
\hline
\end{tabular}

${ }^{\mathrm{a}} \mathrm{M}(\%)$ means the mean value of inhibition ratio, ${ }^{*}, \mathrm{p}<0.05,{ }^{* *}, \mathrm{p}<0.01$, compared with control group.

Figure 3. Photos of acridine orange staining (A: compound 10, B: control).

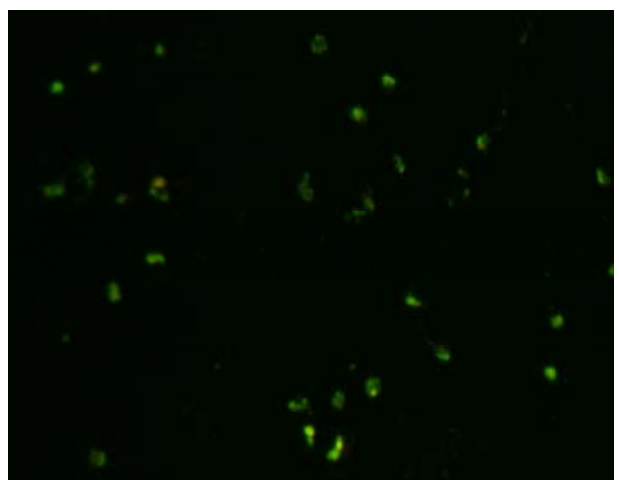

(A)

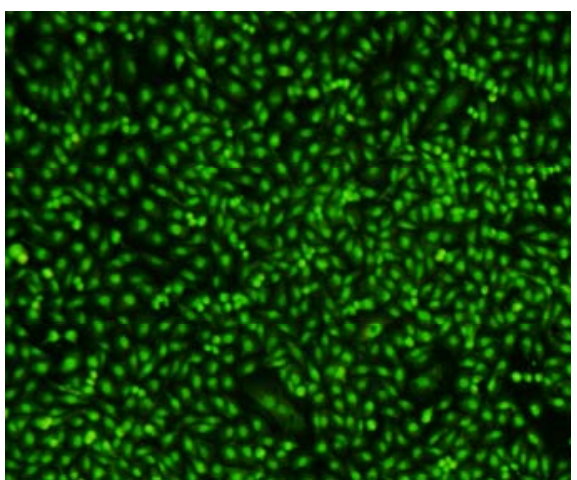

(B) 


\section{Experimental}

\subsection{General}

1D and 2D NMR experiments were performed on a Bruker AM-400 or DRX-500 spectrometer. Chemical shifts $(\delta)$ are expressed in ppm with reference to the solvent signals. Mass spectra were recorded on a VG Autospec-300 spectrometer under $70 \mathrm{eV}$. Optical rotation was measured with a Horiba SEPA-300 polarimeter. A Bio-Rad FTS-135 spectrophotometer was used for scanning IR spectroscopy of compounds with $\mathrm{KBr}$ pellets. Column chromatography was performed on silica gel (200-300 mesh, Qingdao Marine Chemical Inc., Qingdao, People's Republic of China), silica gel H (10-40 $\mu \mathrm{m}$, Qingdao Marine Chemical Inc.) and MCI gel CHP20P (75-150 $\mu \mathrm{m}$, Mitsubishi Chemical Corporation, Tokyo, Japan). Fractions were monitored by TLC and spots were visualized by heating plates spraying with $15 \% \mathrm{H}_{2} \mathrm{SO}_{4}$ in $\mathrm{EtOH}$.

\subsection{Plant Material}

The aerial parts of E. acerifolia were collected from Deqin, Yunnan Province, People's Republic of China. The plant material was identified by Dr. Yuanwen Duan. A voucher specimen (No.Yangyp 080724) was deposited at Kunming Institute of Botany, Chinese Academy of Sciences.

\subsection{Extraction and Isolation}

The dry aerial parts of E. acerifolia $(35 \mathrm{~kg}$ ) were powdered and extracted with $70 \%$ aqueous acetone $(3 \times 25 \mathrm{~L})$ for $24 \mathrm{~h}$ at room temperature. The solvent was concentrated in vacuo to give a crude extract. The extract was then dissolved in $\mathrm{H}_{2} \mathrm{O}$ and partitioned with EtOAc. The EtOAc portion was subjected to column chromatography over MCI gel eluting with $95 \% \mathrm{EtOH}$ and concentrated in vacuo. The residue (1532g) was the subjected to column chromatography over silica gel (80-100 mesh), eluting with petroleum ether- $\mathrm{Me}_{2} \mathrm{CO}$ (from 1:0 to 1:1) to afford fractions $\mathrm{A}-\mathrm{D}$. Fraction A was subjected to column chromatography over silica gel (petroleum ether/acetone) to yield 17 (385 mg). Fraction B was subjected to column chromatography over silica gel $\left(\mathrm{CHCl}_{3} / \mathrm{Me}_{2} \mathrm{CO}\right)$ and Sephadex LH-20 $\left(\mathrm{CHCl}_{3} / \mathrm{MeOH}\right)$ to give $1(27 \mathrm{mg}), \mathbf{2}(9 \mathrm{mg}), \mathbf{4}(1,369 \mathrm{mg}), \mathbf{5}(565 \mathrm{mg}), \mathbf{9}(7 \mathrm{mg}), \mathbf{1 0}$ (945 mg), 11 (187 mg), 12 (143 mg), 14 (12 mg), 15 (40 mg). Fraction C was subjected to column chromatography over silica gel $\left(\mathrm{CHCl}_{3} / \mathrm{Me}_{2} \mathrm{CO}\right)$ and Sephadex $\mathrm{LH}-20\left(\mathrm{CHCl}_{3} / \mathrm{MeOH}\right)$ to obtain $3(21$ $\mathrm{mg}), 6(4 \mathrm{mg}), 7(3 \mathrm{mg}), \mathbf{8}(2 \mathrm{mg}), \mathbf{1 3}(73 \mathrm{mg})$. Fraction D was purified by repeated column chromatography over silica gel $\left(\mathrm{CHCl}_{3} / \mathrm{MeOH}\right)$ to afford $16(46 \mathrm{mg})$.

Compound 1: white crystals; mp 189.2-190.7; $[\alpha]_{\mathrm{D}}^{25.1}=-34.5\left(\right.$ c 0.85, $\left.\mathrm{CHCl}_{3}\right) ; \mathrm{UV}_{\max }\left(\mathrm{CHCl}_{3}\right): 198,205$, $240 \mathrm{~nm}$; IR (KBr); $v_{\max } 3381,2919,1461,1444,1318,1194,1123,1058,1040 \mathrm{~cm}^{-1}$; For ${ }^{1} \mathrm{H}-$ and ${ }^{13} \mathrm{C}-$ NMR see Table 1; HRESIMS m/z 341.2099 (calcd for $\mathrm{C}_{20} \mathrm{H}_{30} \mathrm{O}_{3} \mathrm{Na}, 341.2092$ ). 


\subsection{Antiangiogenesis and antiproliferative assays}

\subsubsection{Antiangiogenesis [23]}

Stock solutions $(10 \mathrm{mg} / \mathrm{mL})$ of all samples were prepared by dissolving the test compounds in $100 \%$ DMSO. These solutions were diluted in sterile salt water $(5 \mathrm{mM} \mathrm{NaCl}, 0.17 \mathrm{mM} \mathrm{KCl}, 0.4 \mathrm{mM}$ $\mathrm{CaCl}_{2}, 0.16 \mathrm{mM} \mathrm{MgSO}_{4}$ ) to obtain solutions with the test compounds dissolved in $0.1 \%$ DMSO. These solutions were aliquoted into 96-well plates, and embryos at $24 \mathrm{hpf}$ (hours post fertilization) were also transferred randomly into the above wells. After $24 \mathrm{~h}$ of treatment, the intersegmental vessels of embryos were visualized with green fluorescent protein labeling and endogenous alkaline phosphatase staining. The antiangiogenic activities of compounds were calculated from the inhibition ratio of angiogenesis. PTK787 was used as the positive control.

\subsubsection{Antiproliferative [24]}

A549 lung cancer cells were cultured in RPMI 1640 medium at $37^{\circ} \mathrm{C}$ with $5 \% \mathrm{CO}_{2}$ and $95 \%$ air, supplemented with $10 \%(\mathrm{v} / \mathrm{v})$ bovine calf serum and $80 \mathrm{U} / \mathrm{ml}$ penicillin/streptomycin. The cells were seeded onto 96-well plates and treated with compounds at 25, 50 and $100 \mu \mathrm{g} / \mathrm{mL}$ for $48 \mathrm{~h}$, respectively. Cell viability was determined by MTT (3-(4,5-dimethylthiazol-2-yl)-2,5,-diphenyltetrazolium) assay according to Price et al. The light absorption was measured at 570nm using Spectra MAX 190 microplate spectrophotometer (GMI Co., USA). Inhibition rate was calculated by the formula:

$$
\text { Inhibition }(\%)=100 \%-\left(\mathrm{OD}_{\text {treatment }}-\mathrm{OD}_{\text {blank }}\right) /\left(\mathrm{OD}_{\text {control- }} \mathrm{OD}_{\text {blank }}\right) \times 100 \%
$$

The cells were incubated with compounds $(100 \mu \mathrm{g} / \mathrm{mL})$ for $48 \mathrm{~h}$, and stained with $0.1 \mathrm{mg} / \mathrm{mL}$ of acridine orange $(\mathrm{AO})$ at room temperature for $5 \mathrm{~min}$. Then the cells were observed and photographed using the fluorescent stereo microscope (Olympus, Japan).

\section{Conclusions}

Our current research led to the isolation of a new kaurane diterpenoid (1), together with 16 known compounds 2-17 from the aerial parts of Excoecaria acerifolia. Their structures were identified by extensive spectral evidence, including HSQC, HMBC, ${ }^{1} \mathrm{H}^{-}{ }^{1} \mathrm{H}$ COSY, ROESY experiments. Most of isolated constituents are phenolic compounds, which hints that the major chemical constituents in the aerial parts of Excoecaria acerifolia may be phenolics. The antiangiogenic and antiproliferative activities of part of isolates were evaluated and some of them are bioactive.

\section{Acknowledgements}

The authors are grateful to the Department of Instrumental Analysis of Kunming Institute of Botany for measuring UV, IR, NMR, and mass spectra. The work was supported by the West Light Foundation of the Chinese Academy of Sciences (awarded to Xiaoli Li), MOST grant (2008BAD98B06), MAPs Traditional Knowledge Network in Southwest China from MAPPA/ICIMOD, AND the Ford Foundation (1075-0729 and 1090-0448). 


\section{References and Notes}

1. Tenji, K.S.; Takao, K.S.; Takashi, M.K.; Fujiwara, Y. Novel diterpenes, excoecarins M and N from the resinous wood of Excoecaria agallocha. Tetrahedron. Lett. 2000, 41, 3419-3422.

2. Anjaneyulu, A.S.R.; Rao, V.L. Seco diterpenoids from Excoecaria agallocha. Phytochemistry 2003, 62, 585-589.

3. Wu, Z.Y.; Lu, A.M.; Tang, Y.C.; Chen, Z.D.; Li, D.Z. The Families and Genera of angiosperms in CHINA, a Comprehensive Analysis; Science Press: Beijing, China, 2003; p. 586.

4. Jin, Z.Z. Study on the floristic elements of seed plant in the dry-warm valleys of Yunnan and Sichuan. Guihaia 1998, 18, 313-321.

5. Anjaneyulu, A.S.R.; Rao, V.L.; Sreedhar; Karanam. Ent-kaurane and Beyerane Diterpenoids from Excoecaria agallocha. J. Nat. Prod. 2002, 65, 382-385.

6. Adolf, N.; Peter, P.; Eric, E.C. Dhurrin,(-)-catechin, flavonol glycosides and flavones from Chamaebatia foliolosa. Phytochemistry 1987, 26, 1546-1547.

7. El-Sayed, N.H.; Wojciaska, M.; Drost-Karbowska, G.K.; Matiawska, I.; Williams, J.; Mabry, T.J. Kaempferol triosides from Silphium perfoliatum. Phytochemistry 2002, 60, 835-838.

8. Xie, M.Y.; Wang, Y.X.; Yi, X.; Wang, X.R. A study on the structure and contents of Flavonoids in the leaves of Cyclocarya paliurus (Batal.) II jinsk. Chin. J. Anal. Chem. 2004, 8, 1053-1056.

9. Chen, Y.H.; Feng, F.; Ren, D.C.; Xie, N. Chemical constituents from the aerial part of Callicarpa kwangtungensis Chun. Chin. J. Nat. Med. 2008, 2, 120-122.

10. Shen, Z.B.; Theander, O. Flavonoid glycosides from needles of Pinus masssoniana. Phytochemistry 1985, 24, 155-158.

11. Endo, T.; Taguchi, H.; Yosioka, I. The glycosides of plantago major var. japonica Nakai. a new flavanone glycoside, plantagoside. Chem. Pharm. Bull. 1981, 29, 1000.

12. Dawa, Z.M.; Zhou, Y.; Bai, Y. Studies on chemical constituents of Saussurea laniceps. China J. Chin. Mat. Med. 2008, 33, 1032-1035.

13. Guo, Z.J.; Zuo, J.F.; Bo, X.Q.; Sun, Q.S. Study on chemical constituents of Euphorbia hylonoma Hand-Mazz. J. Chin. Med. Mat. 2007, 30, 412-415.

14. Xu, Z.H.; Liu, X.J.; Xu, G.S. Studied on the chemical constituents of roots of Ampelopsis brevipedunculata ( Maxim) trautv. China J. Chin. Mat. Med. 1995, 20, 484-485.

15. Rajapaksa, D.; Keay, B.A. Shikimic acids from furan; methods of stereocontrolled access to 3, 4, 5-trioxygenated cyclohexenes. Can. J. Chem. 1984, 62, 826-827.

16. Yang, L.J.; Yang, X.D.; Li L. Study on chemical constituents of Lagotis yunnanensis. J. Chin. Med. Mat. 2005, 28, 767-768.

17. Yu, Z.B.; Wu, X.; Ye, Y.H.; Zhou, Y.W. Chemical constituents of Glechoma longituba. Nat. Prod. Res. Develop. 2008, 20, 262.

18. Huang, S.; Zhou, X.L.; Wang, H.Y.; Zhang, G.W. Chemical studies on the flowers of Tagetes erecta L. Nat. Prod. Res. Develop. 2006, 18, 57-59.

19. James, J.S.; John, A.P.; Jr. Isolation of free cis and trans-phytol from the red alga Gracilaria andersoniana. Phytochemistry 1976, 15, 1076-1077.

20. Kuai, Y.H.; Bi, Z.M.; Li, P.; Zhang, Y.H. A novel kaurane diterpenoid from the bark of Annona glaba Linn. Chem. Ind. Forest Prod. 2006, 26, 13-15. 
21. Gao, H.; Li, P.Y.; Li, D.K. The study and application of kaurane tetranuclear diterpene comounds by ${ }^{13} \mathrm{C}$ NMR. Chin. J. Mag. Reson. 2000, 17, 335-342.

22. Tenji, K.S.; Takao, K.S.; Fujiwara, Y.; Kiyosawa, S. Excoecarins D, E, and K, from Excoecaria agallocha. J. Nat. Prod. 2000, 63, 344-346.

23. Li, X.L.; Li,Y.; Wang, S.F.; Zhao, Y.L.; Liu, K.C.; Wang, X.M.; Yang, Y.P. Ingol and ingenol diterpenes from the aerial parts of Euphorbia royleana and their antiangiogenic activities. J. Nat. Prod. 2009, 72, 1001-1005.

24. He, Q.X.; Zhu, X.S.; Shi, M.; Zhao, B.X.; Zhao, J.; Zhang, S.L.; Miao, J.Y. Novel morpholin-3one derivatives induced apoptosis and elevated the level of P53 and Fas in A549 lung cancer cells. Bioorg. Med. Chem. 2007, 15, 3889-3895.

Sample Availability: Samples of the compounds 1-17 are available from the authors.

(C) 2010 by the authors; licensee Molecular Diversity Preservation International, Basel, Switzerland. This article is an open-access article distributed under the terms and conditions of the Creative Commons Attribution license (http://creativecommons.org/licenses/by/3.0/). 